\title{
Development of the Intellectual Goods and Services Market as a Basis for Sustainable Development of the Region
}

\author{
Ryasimya Rigayat'evna Tugusheva \\ Saratov national research state University \\ Economic faculty \\ Saratov, Russia \\ ryasimya.tugusheva@mail.ru
}

\begin{abstract}
The article presents segmentation of the market of intellectual goods and services. On the basis of statistical data the key segments of this market - the market of educational services and the market of innovations are characterized at the regional level. The work analyzes these markets' problems hindering the sustainable development of regions.
\end{abstract}

Keywords - intellectual good, intellectual service, educational service, innovations

\section{INTRODUCTION, AIM AND OBJECTIVES OF THE RESEARCH}

Due to transition of the society to a new stage of development, characterized by growing intellectualization of economic activities, accompanied by an increasing role of intangible activities related to the production of knowledge, the market of intellectual goods and services is rapidly developing. Different segments of this market can be defined, however for the regional economy the key ones are those its segments that determine the quality of productive forces of the regional economy and, therefore, the sustainability of its development. The process of intellectual goods production is shown in Figure 1.

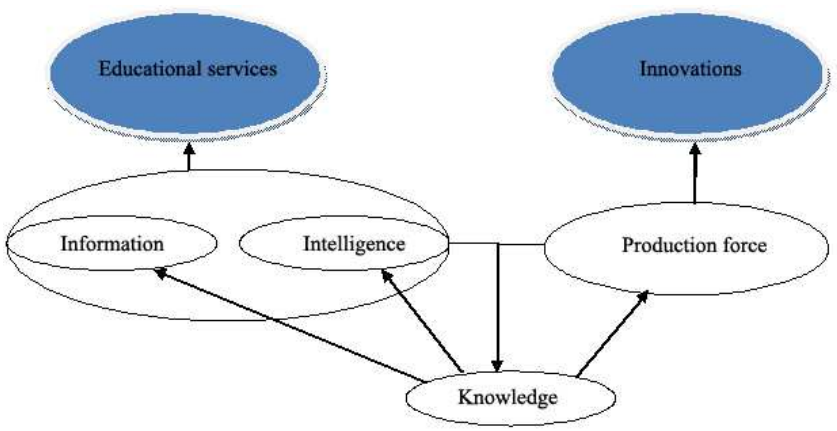

Fig. 1. The process of intellectual goods and services production

The development of intellectual goods and services market in the Russian economy is connected with the regional alignment policy, which makes necessary to consider at the regional level the formation of key segments of this market - the market of educational services and the market of innovations.

The article analyzes these markets (the markets of educational services and innovations) at the regional level, as stimulation of development of the intellectual goods and services market is associated in the Russian economy with the policy of regional alignment.

The aim of the study is to consider in the regional context the problems of demand generation for intellectual goods and services. The objectives of the research are the following:

- identification of factors limiting the demand for innovations in regions;

- determination of regional problems of demand creation for educational services.

\section{METHODS}

The methods used in the study: dialectical, statistical analysis and comparative analysis.

\section{RESULTS}

Universities play a special role in the development of the market of intellectual goods and services. In fact they form the intellectual potential of the region, assess how effective the market of intellectual goods and services functions. The influence of universities on regional innovative development is pointed out in the work of A.A. Firsov and A.A. Narkhov [1]. They managed to prove based on the analysis of correlation dependence by regions that "the more intensive universities and regional businesses interact, the more progressive the innovative development of the region is" [2].

The contribution of universities to the formation of the intellectual potential of the regional economy can be estimated by determining the volume of demand for their educational services. The dynamics of the number of students at all levels of higher education will be analyzed in order to study the demand for educational services at the regional level (Figure 2). 


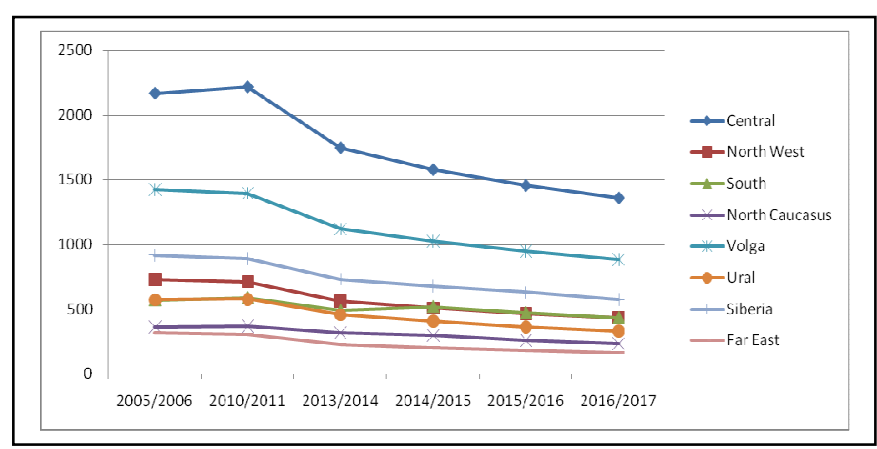

Fig. 2. Dynamics of number of students trained within bachelor, master and specialty programs depending on federal regions for the period from 2005 to 2017 (at the beginning of an academic year, thousands of people)

The figure reflects the negative trend in the number of the contingent in all regions. However, given the fact that the number of students is largely determined by the population in these regions, the ratio of the number of school graduates and the number of students enrolled in universities in each particular region should be considered. The dynamics of this ratio is presented in the Table 1 .

These tables show that in the central regions the number of school graduates enrolled in higher education institutions is higher. Moscow and St. Petersburg can be singled out separately. The number of students enrolled in Moscow higher education institutions exceeded the number of school graduates almost 3 times in 2005, and in 2015 the situation stayed the same. In 2005 in St. Petersburg the number of school graduates was 2 times less than students enrolled in bachelor, master and specialty programs.

TABLE 1. THE RATIO OF THE NUMBER OF SCHOOL GRADUATES AND THE NUMBER OF STUDENTS ENROLLED IN UNIVERSITIES IN FEDERAL DISTRICTS

\begin{tabular}{|c|c|c|c|c|c|c|}
\hline & \multicolumn{2}{|c|}{2005} & \multicolumn{2}{c|}{2010} & \multicolumn{2}{c|}{2015} \\
\hline & $\mathbf{1}^{*}$ & $2^{*}$ & $\mathbf{1}^{*}$ & $2^{*}$ & $\boldsymbol{1}^{*}$ & $\mathbf{2}^{*}$ \\
\hline Central & 435,5 & 499,8 & 301,1 & 416,3 & 272,7 & 380,1 \\
\hline Moscow & 96,2 & 278,3 & 72,3 & 212 & 69,8 & 212 \\
\hline $\begin{array}{c}\text { North } \\
\text { West }\end{array}$ & 166,3 & 174,1 & 103,8 & 148 & 95 & 123,6 \\
\hline $\begin{array}{c}\text { St. Peters } \\
\text { burg }\end{array}$ & 47,3 & 100,6 & 28 & 90,5 & 27,3 & 86 \\
\hline South & 172,7 & 130,2 & 130,4 & 117 & 129,1 & 120,6 \\
\hline $\begin{array}{c}\text { North } \\
\text { Caucasus }\end{array}$ & 129,8 & 80,6 & 106,7 & 69,7 & 95,3 & 57,4 \\
\hline Volga & 438,5 & 329,1 & 290,3 & 280,3 & 248,5 & 245,3 \\
\hline Ural & 165,5 & 132,1 & 109,4 & 114,7 & 103,2 & 90,5 \\
\hline Siberia & 266,1 & 219 & 195,9 & 191,5 & 165,1 & 160,7 \\
\hline Far East & 94,1 & 75,3 & 65,4 & 61,8 & 54,3 & 43,6 \\
\hline
\end{tabular}

* 1 - Graduation of students of state and municipal educational institutions (without night schools) (thousand people); 2 - Admission to bachelor, specialty and master programs (thousand people)

In 2015 this figure increased to 3. Another situation is in the regions of the North Caucasian, Ural, Siberian and Far Eastern federal districts - the number of graduates exceeds there the number of those who have entered institutions of higher education. This trend is typical for the whole reviewed period and points to, on the one hand, the uneven regional development, and on the other hand, to the educational services market dysfunction, which is a consequence of regional inequality. The flow of applicants from distant to central regions leads to the reduction in consumption of educational services in peripheral regions, and this in turn leads to a reduction in the intellectual potential of these regions. This can be explained by the fact that applicants tend to enter universities of the central regions having in mind the prospect of further employment in the same regions. The requisite condition of an increase in the demand for educational services in a region is a growth of the demand for highly skilled labor and availability of job opportunities in this region. The Figure 3 demonstrates the need for workers declared by employers to the employment services bodies.

The figure shows the imbalance of regional labor markets: the need for labor resources in the peripheral regions is growing, especially in the regions of the Far Eastern Federal District. In turn, there is a negative trend in the central regions, in particular, in Moscow and St. Petersburg. This fact indicates the availability of jobs in the peripheral regions and the need to create certain conditions for attracting employees to these regions. There is a program to increase labor mobility in Russia. This program ensures state financial assistance when moving to such regions as Amur Oblast, Arkhangelsk Oblast, Vologda Oblast, Kaluga Oblast, Kamchatka Krai, Krasnoyarsk Krai, Lipetsk Oblast, Magadan Oblast, Murmansk Oblast, Novosibirsk Oblast, Perm Krai, Primorsky Krai, Sakhalin Oblast, Ulyanovsk Oblast, Khabarovsk Krai, Chukotka Autonomous Okrug, i.e. to the regions that according to the chart have a need in labor force.

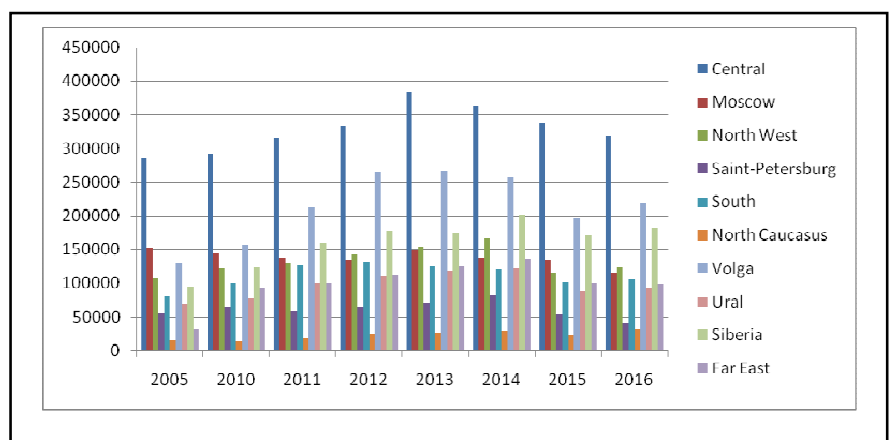

Fig. 3. The need for workers declared by employers to the employment services bodies in federal districts (for the end of the year; the number of people)

Production base and the level of technological potential are equally important conditions for the sustainable development of a region. The work of C. Perez "Technological Revolutions and Financial Capital" [3] proves that the maximum return on consumed intellectual goods and services is observed in highly developed territories. At the same time the spread of innovative products often goes from the central regions to the periphery and occurs with a certain time lag, which leads to a decrease in the amount of intellectual rent received by a region. While new products and technologies are implemented in the economy of peripheral regions more advanced products of intellectual activity appear in the central regions, so the benefits from innovations produced in peripheral regions are reduced. The dynamics of technological costs and the state of innovative development of the federal subjects of Russia are presented in the Table 2 . 
TABLE 2. THE DYNAMICS OF TECHNOLOGY COSTS AND THE LEVEL OF INNOVATIVE DEVELOPMENT OF THE FEDERAL SUBJECTS OF RUSSIA

\begin{tabular}{|c|c|c|c|c|c|c|c|c|c|c|}
\hline & years & Central & North West & South & North Caucasus & Volga & Ural & Siberia & Far East & Crimean \\
\hline \multirow{3}{*}{$\begin{array}{l}\text { The share of innovatively } \\
\text { active enterprises, } \%\end{array}$} & 2010 & 8,6 & 9,4 & 7,5 & 6,2 & 12,3 & 11,5 & 8,2 & 8,6 & - \\
\hline & 2013 & 10,7 & 10,7 & 7,2 & 5,9 & 11,7 & 9,6 & 9,1 & 9,5 & - \\
\hline & 2015 & 10,9 & 9,6 & 7,8 & 4,7 & 10,6 & 7,9 & 8 & 7,2 & 4,5 \\
\hline \multirow{3}{*}{$\begin{array}{l}\text { Expenditures on } \\
\text { technological innovations, } \\
\text { mln. rubles }\end{array}$} & 2010 & $\begin{array}{c}103 \\
963,0 \\
\end{array}$ & 35966,5 & 10066,7 & 6504,8 & 79303,3 & 92205,6 & 48626,7 & 24167,3 & - \\
\hline & 2013 & 305199,2 & 164167,9 & 45169,9 & 5596,8 & $\begin{array}{c}284 \\
845,9 \\
\end{array}$ & $\begin{array}{c}130 \\
916,9 \\
\end{array}$ & 132576,7 & 43955,9 & - \\
\hline & 2015 & 411465,9 & 87877,6 & 70070,1 & 5909,1 & $\begin{array}{c}300 \\
124,5\end{array}$ & $\begin{array}{c}120 \\
131,4\end{array}$ & 140231,8 & 67231,0 & 596,8 \\
\hline \multirow{3}{*}{$\begin{array}{l}\text { The share of expenditures } \\
\text { on technological } \\
\text { innovations, } \%\end{array}$} & 2010 & 1,5 & 1,2 & 0,8 & 2,0 & 1,5 & 1,8 & 1,6 & 2,2 & - \\
\hline & 2013 & 3 & 3,7 & 2,2 & 1,5 & 3,6 & 1,8 & 2,9 & 2,8 & - \\
\hline & 2015 & 3,5 & 1,5 & 2,8 & 1,3 & 3,2 & 1,5 & 2,5 & 3,3 & 0,8 \\
\hline \multirow{3}{*}{$\begin{array}{l}\text { The volume of innovative } \\
\text { goods and services, } \\
\text { mln. rubles }\end{array}$} & 2010 & $\begin{array}{c}290 \\
757,6 \\
\end{array}$ & 120105,5 & 86558,4 & 27682,6 & $\begin{array}{c}545 \\
954,9 \\
\end{array}$ & $\begin{array}{c}109 \\
584,6 \\
\end{array}$ & 46890,0 & 16178,9 & - \\
\hline & 2013 & $\begin{array}{l}1164 \\
102,4\end{array}$ & 409750,4 & 70281,9 & 23889,8 & $\begin{array}{l}1128 \\
642,7\end{array}$ & $\begin{array}{c}189 \\
234,1\end{array}$ & 151362,7 & $\begin{array}{c}370 \\
602,1\end{array}$ & - \\
\hline & 2015 & $\begin{array}{l}1491 \\
536,1 \\
\end{array}$ & 375614,4 & $\begin{array}{c}148 \\
403,7 \\
\end{array}$ & 41437,3 & $\begin{array}{l}1198 \\
881,4 \\
\end{array}$ & $\begin{array}{c}216 \\
378,0 \\
\end{array}$ & 229866,4 & $\begin{array}{c}140 \\
539,4 \\
\end{array}$ & 772 \\
\hline \multirow{3}{*}{$\begin{array}{l}\text { The share of the volume of } \\
\text { innovative products } \\
\text { shipped, \% }\end{array}$} & 2010 & 4,3 & 4,1 & 6,5 & 8,5 & 10,2 & 2,2 & 1,5 & 1,5 & - \\
\hline & 2013 & 11,4 & 9,3 & 3,4 & 6,4 & 14,2 & 2,6 & 3,3 & 23,5 & - \\
\hline & 2015 & 12,8 & 6,3 & 6,0 & 8,9 & 13,0 & 2,7 & 4,1 & 6,9 & 1 \\
\hline
\end{tabular}

A high share of innovatively active organizations is observed in the Volga federal district. The region maintains high values of this indicator despite the negative trend. In the subjects of the Volga federal district in 2010 this figure amounted from $6,4 \%$ in Saratov Oblast to $21,3 \%$ in Perm Krai. The situation changed in 2015. Innovative activity of organizations declined twice, for example in Perm Krai this figure dropped to $10,5 \%$ in 2015. In Samara Oblast the indicator decreased more than twice: in 2010 it was $12,1 \%$, in $2015-5 \%$. In some subjects the changes took the opposite direction. For instance, in the Republic of Tatarstan the level of innovative activity of organizations changed from $14,9 \%$ to $20,5 \%$, in the Chuvash Republic - from 15,7\% to $24 \%$. Despite the small number of subjects in the Ural Federal District the share of innovative enterprises exceeds the same indicator in other federal districts. In 2010 the range of the indicator in the subjects of this federal district extended from $9,8 \%$ in Tyumen Oblast to $15 \%$ in Sverdlovsk Oblast. In 2015 - from 4,2 \% in Kurgan Oblast (in 2010 it was 12,4\%, this figure decreased by 3 times in 2015) to $9,2 \%$ in Chelyabinsk Oblast (in $2010-9,9 \%$ ). The lowest share was in the regions of the North Caucasian Federal District: in 2010 the figure ranged from $0,8 \%$ in the Chechen Republic to $8.3 \%$ in the Kabardino-Balkaria Republic (it decreased to $2,5 \%$ by 2015). In 2015 - from 1,6\% in the Chechen Republic to 7,3\% in the Republic of Dagestan. Overall, the share of innovative organizations in the total number of organizations in Russia was $9,5 \%$ in $2010,10,3 \%$ in 2011 and it declined to $9,3 \%$ in 2015. According to the adopted innovation policy the share of organizations engaged in technological innovations should be $44,25 \%$. However at the moment the real figure is not even close to the stated value.

The determining factor in the innovative activity of an organization is its expenditures on technological innovations. The expenditures on technological innovation increase both in its volume and in the share of total costs of organizations in all federal districts. A large amount of costs is in the Central, Volga and Ural federal districts. The leaders in terms of total costs are the following regions of these federal districts:

Lipetsk Oblast, Moscow, the Republic of Tatarstan, Nizhny Novgorod Oblast, Tyumen Oblast and Chelyabinsk Oblast.

An important indicator of innovation activity in a region is a volume of production of innovative goods and services. The first place in this indicator, as in the previous, takes the Volga Federal District, the second place - the Central Federal District. The leading position of the Volga Federal District is provided by its two subjects - the Republic of Tatarstan (in 2010 - 160890,1 million rubles, in 2015 - 365965,3 million rubles) and Samara Oblast (in 2010 - 92191,1 million rubles, 2015 - 217788,9 million rubles). The leaders of the Central Federal district are Moscow (from 35414,1 million rubles in 2010 to 703190,3 million rubles in 2015) and Moscow Oblast (88900,3 million rubles in 2010 to 147421,3 million rubles in 2015). The lowest figures show the North Caucasian Federal District: indicators of its subjects range from 0,7 million rubles in the Republic of Ingushetia to 19894,6 million rubles in Stavropol Krai in 2010. In 2015 the situation stayed unchanged: from 5.4 million rubles in the Republic of Ingushetia to 39776,8 million rubles in Stavropol Krai. In 2013 some regions of the North Caucasian Federal District did not demonstrate the production of innovative products at all. These regions include the Republic of Ingushetia and the Chechen Republic. As for the innovative products of industrial production the number of such regions is increasing. The Republic of Karachay-Cherkessia (2014 and 2015) and the Republic of North Ossetia-Alania (2013, 2014 and 2015) have joined the above-mentioned regions.

According to the Protocol of the Interdepartmental Commission on Science and Innovation Policy the share of products in the total produced volume should be $18 \%$. This figure has been reached by most of the regions of the Volga Federal District (the republics of Tatarstan and Mordovia, as well as Nizhny Novgorod, Samara and Ulyanovsk oblasts) and Sakhalin Oblast which relates to the Far Eastern Federal District (Table 3).

Such a large share of shipped innovative products in Sakhalin oblast is due to the fact that there is a serious scientific, technical and innovative potential in the oil and gas 
sector at the enterprises-operators of projects Sakhalin-1 and Sakhalin-2. These projects have a significant scientific component aimed at the construction of so called "smart" wells. In 2015 the costs of technological innovation in Sakhalin oblast were 50577704,6 million rubles spent on the acquisition of machinery and equipment out of 51041276,4 million rubles of the total amount (this is a high figure compared to other regions).

TABLE 3. DYNAMICS OF THE SHARE OF SHIPPED INNOVATIVE PRODUCTS IN THE REGIONS THAT HAVE REACHED A PREDETERMINED VALUE (18 \%) (PROCENTS)

\begin{tabular}{|l|c|c|c|c|c|c|}
\hline $\begin{array}{l}\text { The subject } \\
\text { of the } \\
\text { Russian } \\
\text { Federation }\end{array}$ & \multicolumn{7}{|c|}{ The share of shipped innovative products } \\
\hline & $\mathbf{2 0 1 0}$ & $\mathbf{2 0 1 1}$ & $\mathbf{2 0 1 2}$ & $\mathbf{2 0 1 3}$ & $\mathbf{2 0 1 4}$ & $\mathbf{2 0 1 5}$ \\
\hline $\begin{array}{l}\text { Republic of } \\
\text { Mordovia }\end{array}$ & $\mathbf{2 3 , 1}$ & $\mathbf{2 2 , 0}$ & $\mathbf{2 2 , 9}$ & $\mathbf{2 3 , 9}$ & $\mathbf{2 6 , 9}$ & $\mathbf{2 7 , 0}$ \\
\hline $\begin{array}{l}\text { Republic of } \\
\text { Tatarstan }\end{array}$ & 15,6 & 14,9 & $\mathbf{1 8 , 4}$ & $\mathbf{2 1 , 1}$ & $\mathbf{2 0 , 5}$ & $\mathbf{2 0 , 4}$ \\
\hline $\begin{array}{l}\text { Nizhny } \\
\text { Novgorod } \\
\text { Oblast }\end{array}$ & 10,2 & 17,1 & 17,0 & $\mathbf{1 8 , 1}$ & $\mathbf{2 1 , 3}$ & 15,8 \\
\hline $\begin{array}{l}\text { Samara } \\
\text { Oblast }\end{array}$ & 14,2 & $\mathbf{2 1 , 5}$ & $\mathbf{2 4 , 5}$ & $\mathbf{2 2 , 9}$ & $\mathbf{2 1 , 1}$ & $\mathbf{1 9 , 1}$ \\
\hline $\begin{array}{l}\text { Ulyanovsk } \\
\text { Oblast }\end{array}$ & 17,6 & $\mathbf{1 9 , 8}$ & 8,5 & 15,1 & 12,0 & 13,2 \\
\hline $\begin{array}{l}\text { Sakhalin } \\
\text { Oblast }\end{array}$ & - & $\mathbf{5 3 , 9}$ & $\mathbf{5 7 , 4}$ & $\mathbf{5 7 , 8}$ & $\mathbf{6 0 , 1}$ & 13,9 \\
\hline
\end{tabular}

\section{CONCLUSIONS AND PROSPECTS FOR THE DEVELOPMENT OF THE RESEARCH AREA}

The modern Russian economy is characterized by uneven regional development. Currently there are donor and recipient regions in its structure. Donors are the central regions with high capital availability attarcting all kinds of resources in its economic activity: financial, labor and intellectual. Recipient regions are the regions of the periphery with low capital availability and an outflow of resources. Regards to the functioning of key segments of intellectual goods and services market this problem might be presented as follows: the demand for intellectual goods and services is higher in more capital-rich regions. This manifests the regularity in the development of economic relations between the center and the periphery. Intellectual resources are pulled into the center, where the need for them is higher, since the economic activity is higher there. Availability of the solvent demand for intellectual resources in the central regions leads to the movement of these resources to the center; their reproduction in the central regions has an extended character. Intellectual production is developing intensively, and that is typical both for production and dissemination of innovations and for investing in people, in development of higher education in the region. Therefore intellectual reproduction is narrowed on the periphery, where there is a shortage of financial resources and, as a rule, these regions have accumulated debts and are limited in their financial capabilities. Unregulated functioning of the intellectual goods and services market does not lead to the growth of the intellectual potential of the region, on the contrary, it increases the uneven regional development. On the basis of economic literature it can be concluded that this problem is studied insufficiently. The strategies generally mean that the state support should be provided to those regions which have an advantage in the scientific and technological potential and conditions of its implementation.

\section{References}

[1] A.A. Firsova and A.A. Narkhova Universities impact on innovative development of regions: an empirical analysis. Izv. Saratov Univ. (N.S.), Ser. Economics. Management. Law. 2015, vol. 15, iss 2, pp. 154-160.

[2] A.A. Firsova and A.A. Narkhova Universities impact on innovative development of regions: an empirical analysis. Izv. Saratov Univ. (N.S.), Ser. Economics. Management. Law. 2015, vol. 15, iss 2, pp. 154-160.

[3] Carlota Perez Technological Revolutions and Financial Capital. The Dynamics of Bubbles and Golden Ages. Edward Elgar Cheltenham, UK Northampton, MA, USA. - 2011. P. 231. 